\title{
Characterization of the recD gene of Neisseria gonorrhoeae MS11 and the effect of recD inactivation on pilin variation and DNA transformation
}

\author{
Michael S. Chaussee, ${ }^{1}$ Jeanne Wilson ${ }^{1}$ and Stuart A. Hill1,2 \\ Author for correspondence: Michael S. Chaussee. Tel: +1 4063639306 . Fax: +1 4063639204. \\ e-mail:mchaussee@nih.gov
}

\footnotetext{
1 Laboratory of Microbial Structure and Function, Rocky Mountain Laboratories, NIAID, NIH, Hamilton, MT 59840, USA

2 Department of Biological Sciences, Northern Illinois University, DeKalb, IL 60115, USA
}

\begin{abstract}
Pilin antigenic variation in Neisseria gonorrhoeae may result following intrachromosomal recombination between homologous pil genes. Despite extensive study, recA is the only previously characterized gene known to be involved in this process. In this study, the gonococcal recD gene, encoding one subunit of the putative RecBCD holoenzyme, was characterized and its role in pilin variation assessed. The complete recD gene of $\boldsymbol{N}$. gonorrhoeae MS11 was cloned and its nucleotide sequence determined. The gonococcal recD gene complemented a defined Escherichia coli recD mutant, based on plaque formation of bacteriophage $\lambda$ and the restoration of ATP-dependent nuclease activity. Inactivation of the gonococcal recD gene had no measurable effect on cell viability or survival following UV exposure, but did decrease the frequency of DNA transformation approximately threefold. The frequency at which nonparental pilin phenotypes were spawned was 12-fold greater in MS11 recD mutants compared with the parental MS11 rec ${ }^{+}$strain. Similar results were obtained using recD mutants that were not competent for DNA transformation. Complementation of the MS11 recD mutant with a wild-type recD gene copy restored the frequency of pilin phenotypic variation to approximately wild-type levels. The nucleotide changes at pilE in the recD mutants were confined to the variable regions of the gene and were similar to changes previously attributed to gene conversion.
\end{abstract}

Keywords: Neisseria, recD, pilin variation, DNA transformation

\section{INTRODUCTION}

Neisseria gonorrhoeae (gonococcus) is particularly adept at modulating the expression and antigenicity of several surface-exposed proteins (reviewed by Swanson et al., 1992). Mechanistically these changes can occur through RecA-independent processes (phase variation of opa gene expression and lipooligosaccharide biosynthesis genes) and by RecA-dependent homologous recombination, as exemplified by pilin antigenic variation. Furthermore, because the gonococcus is naturally competent for DNA transformation, additional genetic

Abbreviation: DUS, DNA uptake sequence.

The GenBank accession number for the sequence reported in this paper is AF058330. diversity can occur through the horizontal transfer of rearranged alleles (Smith et al., 1991). The dynamic nature of the gonococcal surface may potentiate the survival of the bacterium within its human host, by contributing to its ability to evade the human immune response.

The pilin polypeptide (encoded by the pilin expression locus pilE) can be polymerized to form the major component of the pilus organelle (reviewed by Seifert, 1996; Swanson \& Koomey, 1989). Pili are thin hair-like structures on the surface of the bacterium that are required for virulence (Kellogg et al., 1963; Swanson, 1973; Swanson et al., 1971, 1987). Pilin variants arise through the genetic alteration of pilE. Rearrangement at pilE occurs primarily through an intracellular (Facius \& Meyer, 1993; Swanson et al., 1990; Zhang et al., 1992) gene-conversion-like event whereby a variant pil gene 
sequence ( $p i l S$ ) replaces the homologous gene sequence that resides at the pilE locus (Haas \& Meyer, 1986; Swanson et al., 1986). Pilin variants also occasionally arise through pilE deletion events between direct oligonucleotide repeats (Hill et al., 1990) or by an intercellular DNA-transformation-mediated route (Gibbs et al., 1989; Seifert et al., 1988). However, in contrast to intracellular events where discrete segments of pil DNA are transferred from pilS loci to pilE, genetic variation via the transformation route tends to be restricted to the exchange of intact pilE alleles (Hill, 1996). Despite extensive study, the molecular mechanism of pilin antigenic variation has not been defined.

In other organisms (e.g. Escherichia coli, Salmonella typhimurium and Saccharomyces cerevisiae) insight into genetic recombination has relied heavily on the use of defined $r e c$ mutations (reviewed by Kowalczykowski $e t$ al., 1994). In contrast, surprisingly few gonococcal rec mutants have been constructed. Previous efforts have demonstrated a requirement for RecA in pilin gene rearrangements (Koomey \& Falkow, 1987; Koomey et al., 1987). However, RecA is required for homologous strand invasion and participates in essentially all pathways of homologous recombination. As a result, a $\operatorname{rec} A$ null mutation does not provide insight into the roles that other $r e c$ gene products may play in the initial steps of homologous recombination, including pilin antigenic variation. Therefore, it is anticipated that numerous other $r e c$ gene products, including $\operatorname{RecB}, \operatorname{RecC}$ and $\operatorname{Rec} \mathrm{D}$, may be involved in the initial steps of pilin antigenic variation. Identification of the gene products involved in pilin variation, coupled with the knowledge of their substrate specificities and enzymic activity, should help to define the molecular pathway of pilin antigenic variation.

The recD gene encodes one subunit of the RecBCD holoenzyme, an ATP-dependent exonuclease present in many bacterial species (Brcic-Kostic et al., 1991; Kowalczykowski et al., 1994; Kuzminov et al., 1994; Myers \& Stahl, 1994). RecBCD, or exonuclease V (Exo V), is involved in the generalized recombination pathway of $E$. coli. Exo V activity is specific for the end of duplex DNA and the enzyme acts by degrading duplex DNA until it encounters an octomeric DNA sequence (a Chi site), at which point the enzyme changes from an ATP-dependent exonuclease into a DNA helicase (reviewed by Myers \& Stahl, 1994). Accompanying this transition is either the loss or inactivation of the RecD subunit (Dixon \& Kowalczykowski, 1993; Myers et al., 1995a), which allows recombination to be focused within the interval adjacent to the encountered Chi site (Myers et al., 1995b). E. coli recD mutants are hyper-recombinogenic for recombination (Thaler et al., 1989), in contrast to $r e c B$ or $r e c C$ mutants which are recombinationdeficient in the absence of an alternative pathway for recombination (reviewed by Clark, 1973; Sargentini \& Smith, 1986). Moreover, recD mutations also enhance recombination following bacterial conjugation in $E$. coli or DNA transduction in S. typhimurium (Lovett et al., 1988; Miesel \& Roth, 1994), as well as allow chromo- somal transformation of $E$. coli with linearized plasmid DNA molecules (Russell et al., 1989).

In this study, the recD gene from N. gonorrhoeae MS11 was identified and characterized. The effect of inactivation of the $r e c D$ gene in this strain on pilin variation and transformation was analysed.

\section{METHODS}

Bacterial strains, plasmids, media and growth conditions. Bacterial strains, plasmids and bacteriophage are described in Table 1. N. gonorrboeae was grown on phosphate-buffered agar medium containing IsoVitaleX (Becton Dickinson; GC agar) at $37^{\circ} \mathrm{C}$ in $5 \% \mathrm{CO}_{2}$ (Swanson, 1982). When assessing pilin switching rates, individual colonies were transferred from agar plates on a small piece of sterile Whatman filter paper and resuspended in $1 \mathrm{ml}$ sterile $\mathrm{H}_{2} \mathrm{O}$; appropriately sized aliquots were then plated on fresh agar medium. To select for antibiotic-resistance markers, the following concentrations of antibiotics were added to gonococcal growth medium : $6 \mu \mathrm{g}$ erythromycin $\mathrm{ml}^{-1}, 10 \mu \mathrm{g}$ chloramphenicol $\mathrm{ml}^{-1}$. E. coli was grown on/in Luria-Bertani (LB) agar or broth at $37^{\circ} \mathrm{C}$ and supplemented with the following concentrations of antibiotics, when appropriate: $100 \mu \mathrm{g}$ carbenicillin $\mathrm{ml}^{-1}, 80 \mu \mathrm{g}$ chloramphenicol $\mathrm{ml}^{-1}, 200 \mu \mathrm{g}$ erythromycin $\mathrm{ml}^{-1}$.

Recombinant DNA techniques. Plasmid DNA was isolated using a plasmid purification kit (Qiagen) as described by the manufacturer. Restriction enzymes were purchased from New England Biolabs. The genomic library of strain MS11 was constructed by cloning a partial Sau3A digest of chromosomal DNA isolated from N. gonorrhoeae MS11 into dephosphorylated, BamHI-digested pBR322 (New England Biolabs). Following ligation, the mixture was used to transform $E$. coli $\mathrm{DH} 10 \mathrm{~B}$ and transformants were selected on agar plates containing carbenicillin. The nucleotide sequence of the gonococcal recD gene and the pilE gene of pilin variants was determined by using custom designed oligonucleotides (Table 2) (Genemed Synthesis) and the Dye Terminator Cycle Sequencing Ready Reaction kit with AmpliTaq DNA polymerase (Applied Biosystems). The sequencing reactions were run on an Applied Biosystems 373 DNA sequencer (Applied Biosystems). The sequencing data were analysed using Sequencher version 3.0 software (Gene Codes). PCR was performed using a Perkin Elmer 9600 Thermocycler using either Taq DNA polymerase (Perkin Elmer) or the Expand HiFidelity kit (Boehringer Mannheim). Southern blotting was done by transferring DNA to Nytran membranes (Schleicher \& Schuell) by capillary action followed by baking at $80^{\circ} \mathrm{C}$ (Sambrook et al., 1989). For probes, oligonucleotides were labelled with $\left[\gamma^{-32} \mathrm{P}\right] \mathrm{dATP}$ (Dupont) using T4 polynucleotide kinase (New England Biolabs); DNA fragments were labelled with $\left[\alpha-{ }^{32} \mathrm{P}\right] \mathrm{dATP}$ (Dupont) by using the Klenow DNA polymerase (Sambrook et al., 1989).

Directed mutagenesis of recD. Oligonucleotides RecD1 and RecD4 were used to amplify the recD gene from pSH24. The amplicon was cloned into $\mathrm{pCRII}^{+}$(Invitrogen) and subsequently excised by digestion with EcoRI. The ends were filled-in using Klenow DNA polymerase (New England Biolabs), and the blunt-ended recD fragment was purified from agarose gels using a Qiaex II Gel Extraction kit (Qiagen) and ligated into an EcoRV-linearized pSKII + vector that carried the gonococcal DNA uptake sequence (DUS). The recombinant plasmid was purified from $E$. coli, digested with EcoRV, which cut within the recD gene (the vector EcoRV site was destroyed following ligation of the recD fragment), and 
Table 1. Strains, phage and plasmids

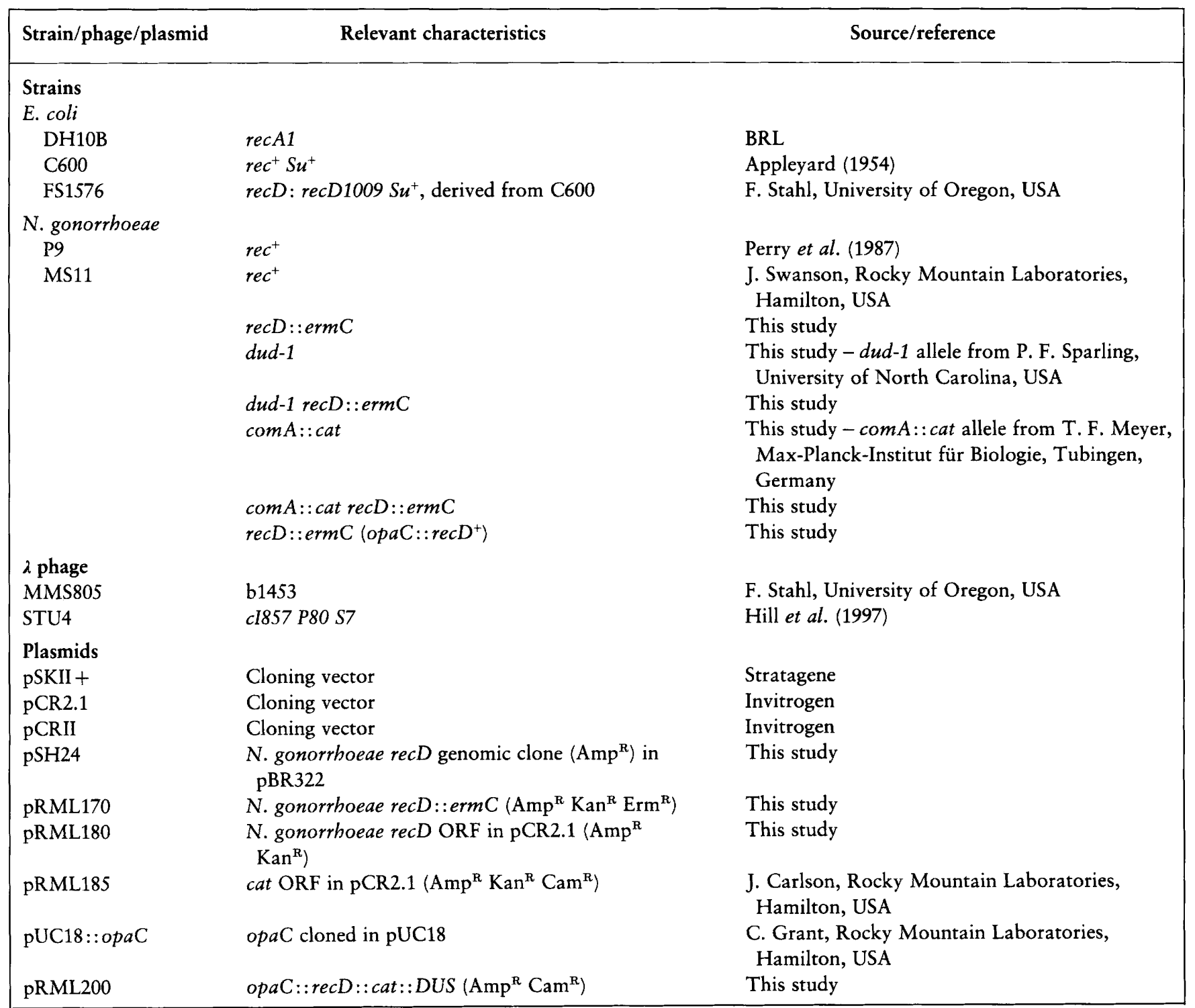

Table 2. Oligonucleotides

\begin{tabular}{|c|c|c|}
\hline Designation & Nucleotide sequence $\left(5^{\prime}-3^{\prime}\right)$ & Reference/source \\
\hline RecD1 & GCAAACCTGTCCACCGACTGC & This study \\
\hline RecD4 & TACCCGCTCAAGCATACTGC & This study \\
\hline RecDF2 & CAGTAGTAGGTTGAGCCCGTTGAAG & This study \\
\hline $\operatorname{RecDB} 2$ & TTATACGACCCCGAATCTGCG & This study \\
\hline PilEF1 & TCCCCTTTCAATTAGGAGT & Hill (1996) \\
\hline PilER2 & CCGATATATTATTTCCACC & Hill (1996) \\
\hline
\end{tabular}

ligated to a blunt-ended erm $\mathrm{C}$ gene fragment. Strains containing the recD::erm C recombinant plasmid ( $\mathrm{RRML170)}$ were selected on plates containing erythromycin and carbenicillin following transformation of E. coli DH10B (Life
Technologies). Plasmid pRML170 was used to transform $N$. gonorrhoeae strain P9 and transformants were selected on agar plates containing erythromycin. PCR and Southern blotting indicated that the transformants contained a single 
copy of the erm $C$ gene in the $r e c D$ locus, which was consistent with allelic replacement of the wild-type $\operatorname{rec} D$ gene with the mutated allele. Genomic DNA isolated from P9 recD was used to transform MS11 and transformants were selected on GC agar plates containing erythromycin.

Construction of MS11 recD merodiploid strain. The recD gene was amplified by PCR from pSH24 using oligonucleotide primers RecDF2 and RecDB2 and cloned into the pCR2.1 (Invitrogen) vector to form the recombinant plasmid designated pRML180. Plasmid pRML180 was cleaved with SpeI in the multiple cloning region of the vector, $3^{\prime}$ to the cloned $\operatorname{rec} D$ gene. The DNA was blunt-ended by using Klenow DNA polymerase, and then ligated with a blunt-ended fragment containing a promoterless cat gene and the gonococcal DUS. The ligation mixture was used to transform E. coli DH10B and transformants were selected on LB agar plates containing chloramphenicol. Following confirmation of the recombinant plasmid construction, the recD-cat-DUS region of the plasmid was excised on a $\mathrm{XbaI}$ and BamHI fragment. The ends were filled-in using Klenow enzyme and ligated into a blunt-ended ClaI site of a pUC18::opaC recombinant plasmid. E. coli transformants were selected on LB agar plates containing chloramphenicol. PCR and restriction enzyme analysis confirmed the construction of the plasmid subsequently designated pRML200. Plasmid pRML200 was used to transform wild-type MS11. Insertion of the recD and cat genes into the $o p a C$ locus was confirmed by Southern blotting and PCR. Inactivation of the wild-type $\operatorname{rec} D$ locus was achieved by allelic replacement using genomic DNA isolated from the MS11 recD::ermC strain. Transformants were selected on agar plates containing erythromycin and construction of the merodiploid was confirmed by Southern blotting and PCR.

Nucleotide sequence of pilin variants. Colonies with nonparental pilin phenotypes were grown for $18 \mathrm{~h}$ on agar plates and cell lysates were prepared by boiling cell suspensions in $50 \mu \mathrm{H}_{2} \mathrm{O}$ for $10 \mathrm{~min}$. The pilE gene was amplified by PCR in a Perkin Elmer 9600 thermocycler with AmpliTaq polymerase (Perkin Elmer) using previously defined primers (Table 2) (Hill, 1996). The PCR product was purified by using Centricon-100 columns (Amicon), and the nucleotide sequence of both strands of the pilE gene was determined as described above.

UV sensitivity and cell viability assays. The sensitivity of gonococcal strains to UV radiation was determined essentially as previously described by Koomey \& Falkow (1987). Nonpiliated, non-opaque gonococci were grown overnight on plates and resuspended and serially diluted in water to a density of approximately $1 \times 10^{8}$ c.f.u. $\mathrm{ml}^{-1}$. Subsequently, $25 \mu \mathrm{l}$ was exposed to $U V$ radiation $(0,25,50,75,125,150$ and $200 \mu \mathrm{J} \times 100)$ by using Stratalinker $1800 \mathrm{UV}$ cross-linker (Stratagene). An MS11 recA strain was used as a control. Cell viability assays were done as previously described by Sandler (1996). Briefly, non-piliated, non-opaque variants of the strains to be tested were grown in liquid broth. At various stages of growth, samples were taken, the $\mathrm{OD}_{600}$ was determined, and viable cell counts were determined by plating defined volumes.

${ }^{3} \mathrm{H}$-labelling of bacteriophage DNA for exonuclease assay. Labelled $\lambda$ DNA was prepared as described previously (Hill et al., 1997). Briefly, a $100 \mathrm{ml}$ culture of an E. coli $\lambda$ lysogen $(\mathrm{cI} 857$ P80 S7) was grown at $34^{\circ} \mathrm{C}$ in the presence of $0.25 \mathrm{mCi}$ $(9.25 \mathrm{MBq})\left[{ }^{3} \mathrm{H}\right]$ thymidine (Dupont). After $6 \mathrm{~h}$ incubation, the temperature of the culture was increased to $42{ }^{\circ} \mathrm{C}$ for $15 \mathrm{~min}$ to induce the phage lytic cycle and the culture was then grown at $37^{\circ} \mathrm{C}$ for an additional $3 \mathrm{~h}$. Cells were then disrupted by lysozyme treatment in conjunction with a chloroform extraction. Phage were purified by $\mathrm{CsCl}$ isopycnic centrifugation. The ${ }^{3} \mathrm{H}$-labelled phage DNA was extracted using phenol/ chloroform and precipitated with ethanol.

Bacteriophage plaque size assay for RecD function. Phage strain MM805 $\mathrm{Gam}^{-} \mathrm{Red}^{-} \mathrm{Chi}^{-}$was kindly provided by Frank Stahl (University of Oregon) and was used to assess RecD function as previously described by Thaler et al. (1989). Plaque size was measured by using a micrometer and dissecting microscope and the data are reported in the text as the mean diameter $(\mathrm{mm}) \pm$ SEM.

DNA transformation. DNA transformation of piliated MS11 strains was performed as previously described (Swanson $e$ t al., 1990). Bacteria were grown on solid medium for 18-24 h. Typically, 20 colonies were then transferred to $0.5 \mathrm{ml}$ broth medium containing $20 \mathrm{mM} \mathrm{MgCl}$ using small pieces of sterile Whatman filter paper. Purified chromosomal DNA isolated from $N$. gonorrboeae that confers resistance to nalidixic acid was added at a concentration of $3.3 \mu \mathrm{g} \mathrm{ml}^{-1}$ and the suspension was incubated at $37^{\circ} \mathrm{C}$ for $30 \mathrm{~min}$. After incubation, the cell suspension was diluted 10 -fold in pre-warmed broth medium containing $1 \%$ IsoVitaleX (Becton Dickinson) and incubated for an additional $5 \mathrm{~h}$ at $37^{\circ} \mathrm{C}, 5 \% \mathrm{CO}_{2}$ prior to plating on agar plates containing $2 \cdot 0 \mu \mathrm{g}$ nalidixic acid $\mathrm{ml}^{-1}$. The frequency of transformation was determined by dividing the number of nalidixic-acid-resistant c.f.u. by the total number of c.f.u. and is given in the text as the mean frequency \pm SEM.

\section{RESULTS}

\section{Cloning and nucleotide sequence analysis of the recD gene from $\mathbf{N}$. gonorrhoeae MS11}

To clone the recD gene from N. gonorrhoeae, the amino acid sequences of the $\operatorname{RecD}$ polypeptides of $E$. coli (Finch et al., 1986a) and Haemophilus influenzae
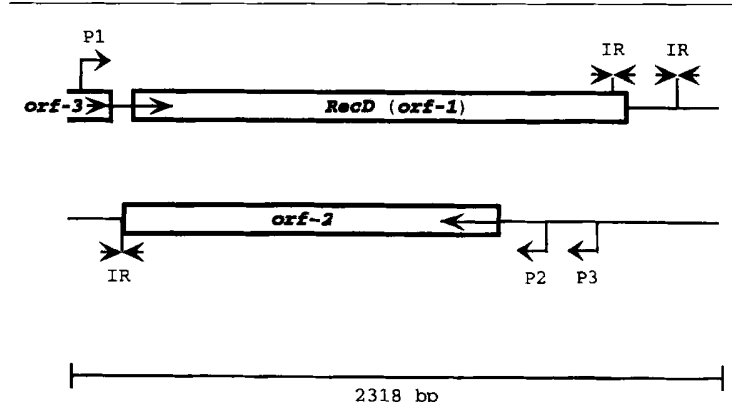

2318 bp

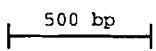

Fig. 1. Physical map of the recD (orf-1) genomic region of MS11. The nucleotide sequence of $2318 \mathrm{bp}$ DNA which contained the recD gene (orf-1) was determined. The recD (orf1) gene was preceded by a putative promoter labelled P1. Two inverted repeats, designated IR, were present downstream of recD (orf-1). Upstream of recD (orf-1) on the same DNA strand $(+)$, a partial ORF (or $f-3)$ was encoded that shared similarity to genes encoding $A B C$ transporters. orf- 2 was encoded on the opposite (-) DNA strand, compared to recD (orf-1), and was preceded by two putative promoters labelled P2 and P3. An inverted repeat (IR) composed of the gonococcal DNA uptake sequence (DUS) was present proximal to the predicted translational stop codon of orf-2. 

M. tuberculosis
----MIITDVDFAVEASGMVRAFNQAGVLDVSDVHVAQRLCAIA GESDERVALAVAVAV -..-MIL QKQLLEAVEHKQLRPL-......-DVQFAL--T-VAGDEHPAVTLAAALLS
influenzae MLSVLHKL KELR ILSOGDYYFAKL
N. gonorrhoeae MLSULYLLRILSQGDYYFAKL-
M. tuberculosis RALRIG GVCVDLLSIAR--
E. COl HDAGE GHVCL PLSRLENN-_- - - - - EASHPLLATCVS--EIGELONWEECLLASOAVSR
H. influenzae WRYTOGNTCSQLDRYLEHNLFGLAYRTTEEDYLAEIHEKIGYLPVEDWQNALCGMMAFTQ

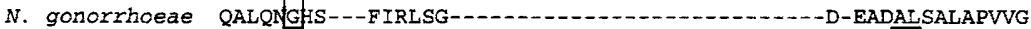

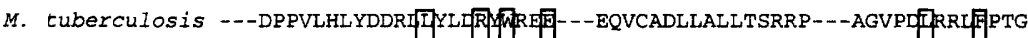
E. COII G--DEPTPMILCGDFLYLNR NCN GRTVARFFNEVNHAIEVDEA---LLAQTTDKI PVS
$H$. influenzae DPVNQIAPMAFQFGAIYFYR MQDIYRIVQY IKNTLKKYRTLAFSYDEIHQKU EKYAPEK

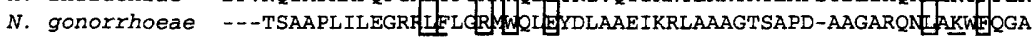

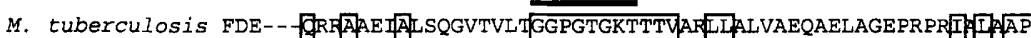 E. $C 01 i$ DEIN-UIKVAAAAVALTRRISVISGGPGTGKTTTVAKLLAALIQMAD--GE-RCRIALAAP
H. influenzae QEKTDWhKVANATA IKSPFSIITGGPGTGKTTTVTRLLLVLQELFD----CKLHIALAAP
N. gonorrhoeae GSE-- QDRDAAAIALLQFFMVITGGPGTGKTTTVAKLLALICGENE--N-LPHChL LAP
M. tuberculosis TGKATARLAEAVRREM----AKLDATDRAR-LGDLHAYT 7 LIGAKPG-ARFRQDRQNR
B. COIi TGKAAARLTESLGKAL----RQLPLTDEQKKRI PEDASTI I LIGAHRGSQRLRHHAGNP
$H$. influenzae TGKAASRLEESIKNALGFMQEKMNVSHSLFNAIPQKASTH HILVNAFNDYTRYNSHNP
N. gonorrhoeae TGKAAMHMARALHRAIN---GFDAPEAVRRHLLKLEGQIMHFLIKLSPPKMQAAFDHIRP

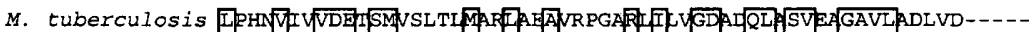

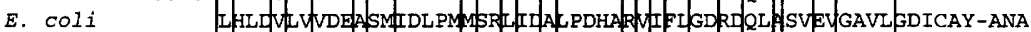

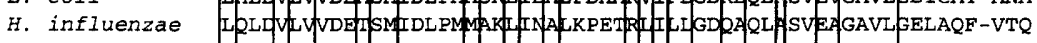

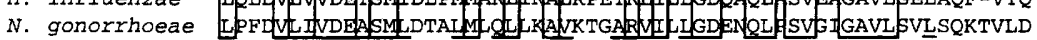

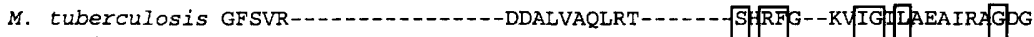
E. $c 01 i$ GFTAERARQLSRLTGTHVPAGTGTEAASLRDSLCLLQR S F F GSDSG IG IAAAINAG GK
$H$. influenzae PYSHEQAAYLLATTGYKVE--GSDCSNPIRDCLCHLTAS RFPKDSCIGAISEFIQKGKA
N. gonorrhoeae GETHQRLAGFLPEHGFS----VSANPPVLAQNTAHLSAS REGDNSGIGRLARAAVAGD-
M. tuberculosis DAVLGLLRSGEERIEFVDD----EDPAPRLRAVLVPHALRLREAALLGAS--------
$E$. $C 01 i$ TAVKTVFOODLTDIEKRLLOS-GEDYIAMLEEALAGYGRYLDLLOARAEP-_...-...
H. influenzae DDSLELFDHYPQELHFNSLNDEGDAVNQVVKSAVENYRTFLKMLDDLRKQKIDPNAKNEQ
$N$. gonorrhoeae EGAWALFDRFPDELEHSEC-----SPNARVERLYRAHKAYWQAVKDGNIE--------
M. tuberculosis -..-DVALATLDEHRIICA R RGPGVLHWNRVQAWLAEET--GQPPWTPWY FGFLL
E. COIi -..-DLIIQAFNEYQI I A P GPFGVAG NERIEQFMQQKRKIHRHPHSRWY GG PVM
H. influenzae GISYAEAIQVQFNSVRA I A RNNNLGVENINKEIALALREQKLLWFRNEODWYIG IIM
N. gonorrhoeae ----AAYAGISDIVILAAhtRDD---AEDFNEAYCSYVRRKMN--IPEHLAYEAGEPIM
M. tuberculosis VTA NDYGLRVY NGD HGVVLAGPT---GLRAVISGASG-PLDVATGRLGDVETMHP MT
$E . \operatorname{col} i$ IAPNDSALGL FNGDHGIALDRGO---GTRVWFAMPDGNIKSVDPSRL PEH EPTWZMIMUK
$H$. influenzae ITENDHNVRL iNGD ACLCLANG-----KVWFGN----REVLTNRIPAHE EAFMYTHK
N. gonorrhoeae IRQNDYALELFNGDUELIMEDVGRQGSLAAYFADADG-FKXUAVSCLPEAEPAFAMTUHK
M. tuberculosis SQGSPVDEVTVLYPRED------SRLLTREILIA

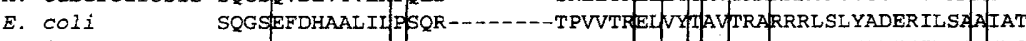
H. influenzae SQGSEFKHTVMVI PTEV-----NPVLSPELVFIGVTRAKKELTVFADEKIWKM AIRQ
N. gonorrhoeae SQGSEYREVWLLAPSDAPSDEGDDALSGLSKEILYMAIIRAREKFVFFGGKKTFCDAVNT
M. tuberculosis RAYRASGDRMRQSTGCG-
E. COIi RTARRSCLAALFSSRE---
H. influenzae TVKRESCIGKLLEDLN---
N. gonorrhoeae VKURETALSMLERVFSQE

Fig. 2. Alignment of the gonococcal RecD polypeptide (ORF-1) with selected RecD polypeptides. The deduced amino acid sequence of the RecD polypeptide from $N$. gonorrhoeae MS11 (ORF-1) is compared to the amino acid sequences of the RecD polypeptides from $M$. tuberculosis (Cole et al., 1998), $E$. coli (Finch et al., 1986b) and $H$. influenzae (Fleischmann et al., 1995). Boxed and underscored regions indicate regions of identity and similarity, respectively. The conserved 'P-loop' sequence is overscored with a bar.
(Fleischmann et al., 1995) were used to search for a similar polypeptide in the translated $N$. gonorrboeae FA1090 genome database (University of Oklahoma) prior to its completion and annotation (Roe et al., 1998). A putative recD gene was identified and the nucleotide sequence facilitated the design of oligonucleotides complementary to the $5^{\prime}$ and $3^{\prime}$ regions of the gene $(\mathrm{RecD} 1$, RecD4). By using PCR, a $1 \cdot 1 \mathrm{~kb}$ portion of the putative recD gene was amplified using genomic DNA isolated from strain MS11 as template DNA. The nucleotide sequence of the PCR product was determined, which confirmed that a recD-like gene had been amplified. Subsequently, the PCR product was radiolabelled and was used to screen a genomic library of $N$. gonorrboeae MS11 by colony hybridization. The probe hybridized to several clones in the library; a single clone ( $\mathrm{pSH} 24$ ) was selected and the nucleotide sequence of $2318 \mathrm{bp}$ neisserial DNA was determined. A schematic depiction of the sequenced region is shown in Fig. 1. Two complete ORFs were identified. One ORF (ORF-1, consisting of $1746 \mathrm{bp}$ ) encoded a 582-amino-acid polypeptide with a predicted molecular mass of $63 \mathrm{kDa}$. A potential ShineDalgarno sequence (AAGG) was present 7 bp upstream of the predicted start codon (AUG). By using MacTargsearch (Mulligan et al., 1984), a potential promoter (P1), centred 169 bp upstream of the translational start site of orf -1 , was identified that shared $38.5 \%$ similarity with the consensus E. coli promoter. Using the BLASTX program, a high scoring match was found between ORF-1 and the RecD polypeptide of E. coli (Finch et al., 
Table 3. Nuclease activity in cellular extracts

Results are expressed as the percentage of TCA-soluble $\left[{ }^{3} \mathrm{H}\right] \mathrm{DNA}$. Assay conditions are described in detail in Methods.

\begin{tabular}{|c|c|c|c|}
\hline \multirow[t]{2}{*}{ Strain and relevant genotype } & \multicolumn{2}{|c|}{$\begin{array}{c}\text { Nuclease } \\
\text { activity }\end{array}$} & \multirow[t]{2}{*}{$\begin{array}{c}\text { Ratio } \\
(+/-\mathbf{A T P})\end{array}$} \\
\hline & $-\mathbf{A T P}$ & $+\mathbf{A T P}$ & \\
\hline E. coli rec ${ }^{+}$ & 8 & 34 & $4 \cdot 3$ \\
\hline E. coli recD & 52 & 24 & 0.5 \\
\hline E. coli recD $/ \mathrm{pSH} 24$ (N. gonorrhoeae rec $\left.D^{+}\right)$ & 21 & 33 & 1.6 \\
\hline
\end{tabular}

1986a). In addition, high scoring matches were found with the putative RecD polypeptides of $H$. influenzae (Fleischmann et al., 1995) and Mycobacterium tuberculosis (Cole et al., 1998). The amino acid sequence of the ORF-1 polypeptide is $58.5 \%$ similar and $34.8 \%$ identical to the RecD protein of E. coli. An alignment of selected RecD polypeptides and ORF-1 showed that several regions are conserved among the polypeptides (Fig. 2), including a consensus 'P-loop', a feature typical of several ATP/GTP-binding proteins (reviewed by Saraste et al., 1990). Based on the similarity of the amino acid sequence of ORF-1 to the $E$. coli RecD polypeptide, ORF-1 was designated RecD and the corresponding gene was designated $\mathrm{rec} D$.

A potential translational start site (AUG) for a second ORF (ORF-2, consisting of $1326 \mathrm{bp}$ ) was preceded by 8 bp by a possible Shine-Dalgarno sequence (GAAA). ORF-2 was encoded on the opposite DNA strand compared to RecD. By using MacTargsearch (Mulligan et al., 1984), two potential promoter regions were identified $159 \mathrm{bp}$ and $324 \mathrm{bp}$ upstream of ORF-2 that were $40.8 \%$ and $42.6 \%$ similar, respectively, to the $E$. coli consensus promoter. An inverted repeat composed of the gonococcal DUS overlapped with the translational stop codon. A search of the GenBank databases did not identify a protein similar to ORF-2.

In contrast to E. coli and other bacterial species, the putative gonococcal recD gene in MS11 was not flanked by the genes encoding either the RecB or RecC subunits of the RecBCD holoenzyme. A portion of a third ORF (ORF-3, consisting of $153 \mathrm{bp}$ ) was present upstream of the $\operatorname{rec} D$ gene that was similar to a variety of genes encoding $A B C$ transporters. There was 66 bp between the end of orf-3 and the predicted start codon of recD. A BLASTX search of the GenBank databases using the $354 \mathrm{bp}$ of sequenced DNA that is downstream of the $r e c D$ gene as the query sequence did not identify a similar protein.

\section{Complementation of an $E$. coli recD mutant with the gonococcal recD gene}

E. coli recD mutants are deficient in Exo V (ATPdependent exonuclease) activity. To determine if the gonococcal recD gene could restore ATP-dependent nuclease activity to an $E$. coli recD mutant, a plasmid that contained the gonococcal recD gene ( $\mathrm{pSH} 24$ ) was introduced into a defined $E$. coli recD mutant by electroporation. Cell extracts were prepared from $E$. coli $\mathrm{rec}^{+}$, E. coli recD and E. coli recD/pSH24 (N. gonorrhoeae $\mathrm{rec}^{+}$). Subsequently, the nuclease activity present in the extracts was determined, both with and without the addition of ATP, by using ${ }^{3} \mathrm{H}$-labelled $\lambda$ DNA as a substrate. Nuclease activity rendered the ${ }^{3} \mathrm{H}$ label acid-soluble, which was quantified by liquid scintillation counting; the results are summarized in Table 3. As expected, the nuclease activity in extracts prepared from the E. coli rec $^{+}$strain was $4 \cdot 3$-fold greater when exogenous ATP was added $\left(34 \%\right.$ acid-soluble $\left.{ }^{3} \mathrm{H}\right)$ compared to that in the absence of exogenously added ATP $\left(8 \%\right.$ acid-soluble $\left.{ }^{3} \mathrm{H}\right)$. In contrast, the nuclease activity in extracts from the E. coli recD strain decreased following the addition of ATP $\left(52 \%\right.$ acid-soluble ${ }^{3} \mathrm{H}$ in the absence of exogenously added ATP compared to $24 \%$ acid-soluble ${ }^{3} \mathrm{H}$ following ATP addition), resulting in a ratio of ATP-dependent to ATP-independent nuclease activity of 0.5 . In the absence of exogenously added ATP, the nuclease activity in extracts prepared from the $E$. coli recD strain was greater $(52 \%$ acidsoluble ${ }^{3} \mathrm{H}$ ) compared to that in extracts from the parental $\mathrm{rec}^{+}$strain $\left(8 \%\right.$ acid-soluble $\left.{ }^{3} \mathrm{H}\right)$. This result may indicate that either there is a compensatory increase in ATP-independent nuclease activity in the absence of Exo V, or alternatively that Exo V inhibits ATPindependent nuclease activity. Similar to results obtained using $E$. coli rec $^{+}$extracts, the nuclease activity in extracts prepared from the $\operatorname{rec} D$ mutant strain that contained the gonococcal recD gene $[$ E. coli $r e c D / p S H 24$ (N. gonorrboeae $\mathrm{recD}^{+}$)] was $1 \cdot 6$-fold greater when exogenous ATP was added $\left(33 \%\right.$ acid-soluble $\left.{ }^{3} \mathrm{H}\right)$ compared to that in the absence of exogenously added $\operatorname{ATP}\left(21 \%\right.$ acid-soluble $\left.{ }^{3} \mathrm{H}\right)$. In addition, in the absence of exogenously added ATP, the nuclease activity detected in extracts from the complemented E. coli recD mutant was less compared to the activity in extracts prepared from the $r e c D$ mutant $\left(21 \%\right.$ acid-soluble ${ }^{3} \mathrm{H}$, $52 \%$ acid-soluble ${ }^{3} \mathrm{H}$, respectively). These results indicated that the gonococcal recD gene could restore ATPdependent nuclease activity to a defined E. coli recD mutant. 

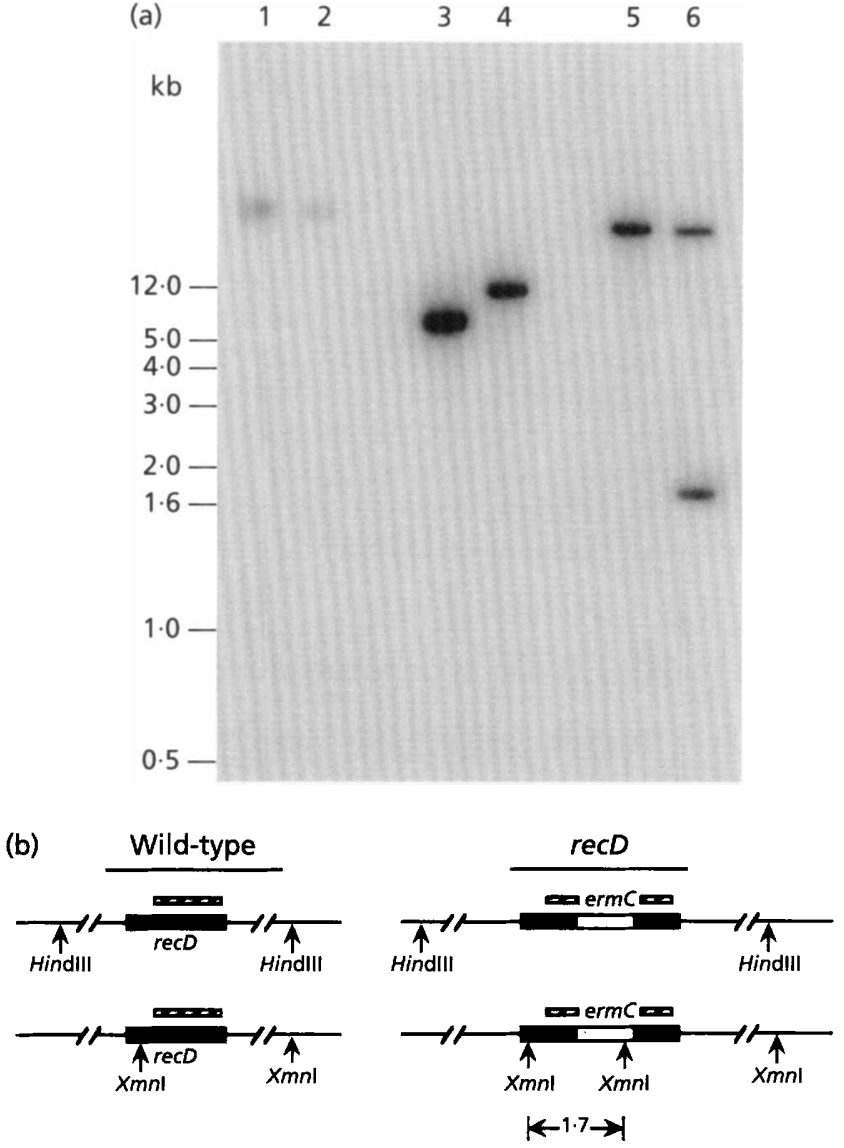

Fig. 3. Southern blot analysis of chromosomal DNA isolated from strains MS11 wild-type and MS11 recD. DNA was isolated from strains MS11 wild-type and MS11 recD and was examined by blot hybridization (a). Lanes: 1, MS11 wild-type genomic DNA (uncut); 2, MS11 recD genomic DNA (uncut); 3, HindIII digest of MS11 wild-type genomic DNA; 4, Hindlll digest of MS11 recD genomic DNA; $5, X \mathrm{mnl}$ digest of MS11 wild-type genomic DNA; $6, X m n l$ digest of MS11 recD genomic DNA. The blot was probed with gonococcal recD specific probe. (b) Schematic presentation of the gonococcal recD locus showing the relative position of the HindIII and $X m n l$ sites. The crosshatched bar shows the approximate hybridization position of the rec $D$ probe.

The plaque size of $\operatorname{Red}^{-} \mathrm{Gam}^{-}$bacteriophage $\lambda$ is significantly influenced by the presence of Exo $V$ activity in the E. coli host (McKittrick \& Smith, 1989; Myers et al., 1995a; Russell et al., 1989). Specifically, larger plaques are formed when the phage infect recD mutants of E. coli, due to the lack of host cell Exo V activity (reviewed by Myers \& Stahl, 1994; Thaler et al., 1989). Therefore, as an additional test to determine if the gonococcal recD gene could complement a recD mutation in $E$. coli, the plaque size of $\mathrm{Red}^{-} \mathrm{Gam}^{-}$phage was used as an indicator of Exo $\mathrm{V}$ activity. In addition, since the recombinant plasmid used to assess ATPdependent nuclease activity ( $\mathrm{pSH} 24$ ) contained a large genomic DNA fragment from MS11, the gonococcal recD gene was amplified by PCR from pSH24 and cloned into the pCR2.1 vector to form the recombinant plasmid designated pRML180. As a control, a cat gene was similarly cloned into pCR2.1 and the plasmid was designated $\mathrm{pRML185}$. These plasmids were then introduced into the $E$. coli $r e c D$ strain by electroporation. The strains were infected with $\mathrm{Red}^{-} \mathrm{Gam}^{-}$bacteriophage and the diameter of the resulting plaques was measured to assess the activity of Exo V. The mean diameter of the plaques formed by $\mathrm{Red}^{-} \mathrm{Gam}^{-}$phage on E. coli recD/pRML180 (N. gonorrhoeae recD ${ }^{+}$) was $1.5 \pm 0.039 \mathrm{~mm}$; significantly smaller compared to the mean diameter of the plaques that formed on the control strain $E$. coli recD/pRML185 (cat) $(2.1 \pm 0.056 \mathrm{~mm} ; P$ value $<0.0001$ ), but slightly larger than those formed on the parental E. coli $\mathrm{rec}^{+}$strain $(1.2 \pm 0.025 \mathrm{~mm}$; $P<0 \cdot 0001)$. These results showed that the gonococcal recD gene was necessary and sufficient to restore Exo V activity to an $E$. coli recD mutant.

\section{Inactivation of the recD gene in MS11 and complementation of the mutant with an intact gene copy}

N. gonorrboeae MS11 recD mutants were obtained by allelic replacement using donor DNA that carried a recD::erm C insertional mutation. The replacement of the wild-type copy with the insertionally inactivated copy of $r e c D$ was confirmed by PCR analysis (data not shown) and Southern blotting (Fig. 3a). To address potential polar effects due to insertion of the heterologous erm $C$ marker into the $r e c D$ locus, an MS11 recD::erm C (opaC::recD ${ }^{+}$) merodiploid strain was constructed that contained an intact copy of the $r e c D$ gene inserted into the opaC locus. Piliated recD mutants of both MS11 and P9 strains had a longer lag phase and an approximately $10 \%$ longer generation time in broth medium compared to piliated MS11 $\mathrm{rec}^{+}$or piliated MS11 recD : : ermC (opaC: : $r e c D^{+}$) merodiploid strains (data not shown). Thus the growth defect was associated with the inactivated $\operatorname{rec} D$ allele and was not strainspecific. However, there was no apparent difference in growth among non-piliated variants of MS11 rec , MS11 recD and MS11 recD : : ermC (opaC : $\mathrm{recD}^{+}$) (data not shown). No difference was detected among the three strains [MS11 $\mathrm{rec}^{+}$, MS11 recD and MS11 recD::ermC $\left(\right.$ opaC: $\left.: \mathrm{rec}^{+}\right)$merodiploid] in viability or their susceptibility to UV irradiation (data not shown). Since N. gonorrhoeae is naturally competent for DNA transformation (Sparling, 1966) the frequency of .DNA transformation was also evaluated among the strains using purified chromosomal donor DNA that carried a single base pair mutation conferring resistance to nalidixic acid. The frequency of transformation of the MS11 $\mathrm{rec}^{+}$strain was $0.018 \pm 0.004$ compared to $0.006 \pm 0.003$ in the MS11 recD mutant strain, a threefold difference $(P=0.073)$. The recD merodiploid strain had a frequency of transformation of $0.012 \pm 0.005$; this was not significantly different from the $\mathrm{rec}^{+}$strain $(P=0.442)$ or the recD mutant $(P=0.358)$. 
Table 4. Effect of recD mutation on the frequency of pilin phenotypic variation

The data represent the mean (SEM) from at least 16 individual colony platings.

\begin{tabular}{|lc|}
\hline Strain & $\begin{array}{c}\text { Frequency of pilin } \\
\text { switching (SEM) }\end{array}$ \\
\hline Wild-type $37^{\circ} \mathrm{C}$ & $0.009(0.01)$ \\
Wild-type $33^{\circ} \mathrm{C}$ & $0.011(0.00)$ \\
recD::ermC & $0.108(0.02)$ \\
recD::ermC & $0.014(0.00)$ \\
(opaC::recD & \\
dud-1 & $0.010(0.00)$ \\
recD dud-1 & $0.092(0.06)$ \\
$\operatorname{comA} A$ & $0.032(0.01)$ \\
recD comA & $0.228(0.04)$ \\
\hline
\end{tabular}

\section{Effect of a gonococcal recD mutation on pilin phenotypic variation}

Differences in colony morphology correlate with the expression (or lack of expression) of different pilin polypeptides (Swanson et al., 1986) and is therefore a sensitive indicator for genetic rearrangement occurring at the pilE locus. To determine if inactivation of the $r e c D$ gene affected pilin variation, the frequency at which progeny displayed a non-parental pilin phenotype was compared among the MS11 $\mathrm{rec}^{+}$, MS11 recD and MS11 recD:: erm C (opaC : $\left.\mathrm{recD}^{+}\right)$merodiploid strains. For each experiment, a single colony was plated at low density on agar plates and the progeny were assessed for the presentation of either a parental or non-parental (which includes both pilus ${ }^{+}$and pilus ${ }^{-}$variants) pilin phenotype. As shown in Table 4, the frequency of progeny with a non-parental pilin phenotype was approximately 12 -fold greater in strain MS11 recD compared with the parental MS11 $\mathrm{rec}^{+}$strain. The presence of an intact $r e c D$ gene copy in the opaC locus of the recD mutant restored the frequency of pilin switching to that of the MS11 rec strain (Table 4) and confirmed that the effect on colony morphology was associated with the mutated $\mathrm{recD}$ allele. Several control experiments were designed to determine if the increase in variant pilin phenotypes in the recD mutant strain was due to either the growth defect or the decrease in the frequency of DNA transformation; both properties associated with piliated $r e c D$ mutants. To determine if the reduced growth rate stimulated changes in the pilin phenotype in wild-type bacteria, the frequency of pilin phenotype variation in MS11 $\mathrm{rec}^{+}$was determined following growth at $33{ }^{\circ} \mathrm{C}$ to mimic the growth rate of the $\operatorname{rec} D$ mutant strain. No significant effect on the frequency of pilin variation was observed under this condition (cf. wild-type $\mathrm{rec}^{+}$bacteria following growth at 33 and $37^{\circ} \mathrm{C}$; Table 4). Although a dramatic difference in the frequency of DNA transformation was not evident following inactivation of the recD gene, it remained unclear if the minor difference in transform- ation (threefold decrease) could significantly influence the frequency of pilin variation. Several gonococcal mutants are available that are not competent for transformation, including $d u d-1$ and a comA mutant (Biswas et al., 1989; Facius \& Meyer, 1993), both of which are deficient in the ability to transport donor DNA to the cytoplasm. To determine if the effect of a recD mutation on the frequency of pilin variation was related to the minor effect on transformation, the frequency of pilin variation was also determined for the following non-competent strains of MS11: dud-1, dud$1 \mathrm{rec} D, \operatorname{com} A, \operatorname{com} A \operatorname{recD}$. As shown in Table 4, an increased frequency of progeny with a non-parental pilin phenotype in non-competent strains of MS11 again correlated with the inactivated $\mathrm{recD}$ allele.

\section{Genetic changes at pile in gonococcal recD mutants}

To confirm that the variant pilin phenotypes spawned by MS11 recD mutants reflected gene-conversion-like events at pilE, as seen in $\mathrm{rec}^{+}$bacteria, and to confirm that the changes in colony morphology used to estimate the frequency of pilin variation correlated with changes in the amino acid sequence of the pilin polypeptide, the pilE nucleotide sequences from 15 piliated colonies displaying a non-parental pilin phenotype were determined and compared to the parental MS11 recD pilE gene sequence. At the amino acid level (Fig. 4), the pilin polypeptide sequences from all 15 non-parental progeny differed compared with the parental polypeptide sequence, with changes occurring exclusively within the variable portions of the polypeptide. Although not all the variable segments in the non-parental pilE genes could be ascribed to a specific published pilS gene copy, several variable segments were traced back to specific pils gene copies. For example, the gene segment that incorporated the amino acid sequence EMASTGVNKEIKD (residues 98-110) in non-parental pilin variants numbers 6 and 13 originated from pilS1 copy 3; likewise, the amino acid sequence GAGNAGKADDVTKAGNDNEKIN (residues 135-156) of variant number 13 was introduced following recombination of pilS1 copy 2 with pilE (Haas \& Meyer, 1986). Moreover, similar types of pilin variants, with characteristic pilE geneconversion-like motifs, were also found in those nonparental variants that were obtained by plating MS11 comA recD bacteria (data not shown). These results confirmed that the characteristic colony morphology of the $\operatorname{rec} \mathrm{D}$ bacteria that were scored as presenting a nonparental pilin phenotype correlated, without exception, to amino acid changes encoded at pilE. In addition, this analysis showed that the variation at the pilE locus in MS11 recD mutants was reminiscent of previously ascribed gene-conversion-like events.

\section{DISCUSSION}

The purpose of this study was to characterize the $r e c D$ gene of $N$. gonorrhoeae, which encodes one subunit of 

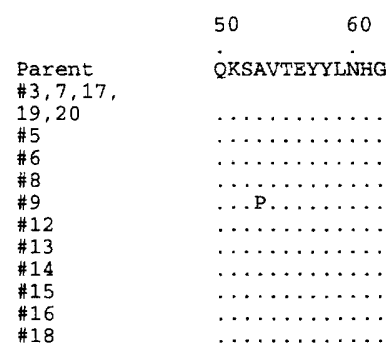

70

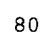

90

100

110

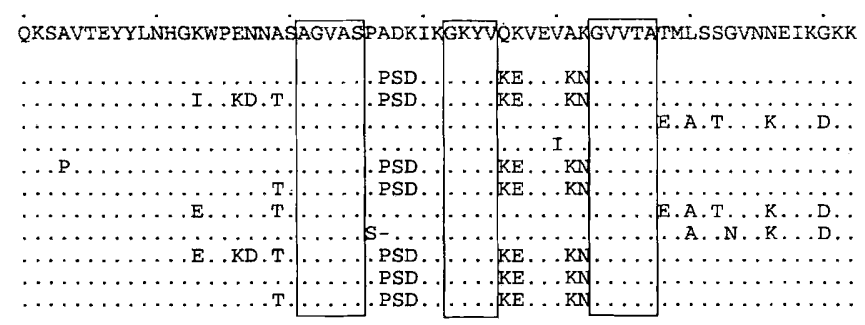

$\begin{array}{llllll}113 & 120 & 130 & 140 & 150 & 160\end{array}$
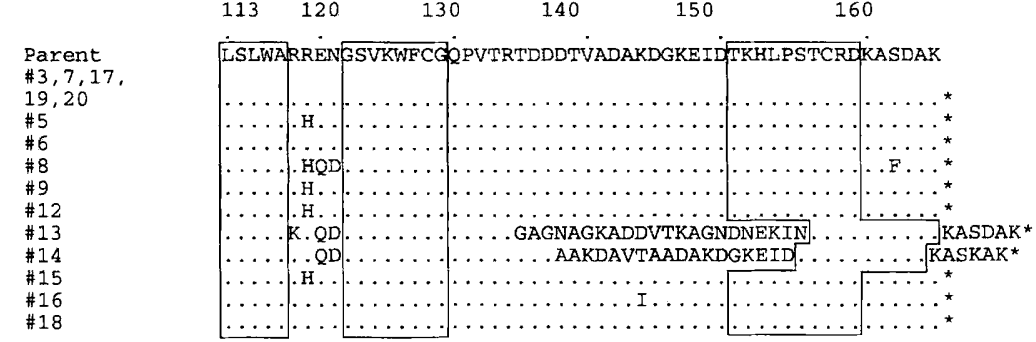

\begin{abstract}
Fig. 4. Amino acid sequence comparison of the MS11 recD parental and non-parental pilin polypeptides. The nucleotide sequence of the pile gene was determined for a parental MS11 recD colony and for 15 progeny colonies that displayed a nonparental pilin phenotype. The deduced amino acid sequences of the variable regions of the pilin polypeptide are compared and are aligned with respect to the position of the constant regions (boxed segments). Amino acids are noted by the single-letter code and their relative numerical positions are designated. Amino acids that differ from the parental sequence are indicated; stops indicate identical amino acids.
\end{abstract}

the putative gonococcal RecBCD holoenzyme, and assess its contribution, if any, to genetic variation at the pilE locus. The recD gene was selected for study based on the prediction that if the RecBCD holoenzyme is involved in recombination at pilE, mutations in either of the genes encoding the RecB or RecC subunits would be likely to abolish pilin variation, similar to a $\operatorname{rec} A$ mutation. However, because a mutation in the recD gene of E. coli has been previously shown to abrogate Exo $\mathrm{V}$ activity, while maintaining the recombinogenic helicase activity of RecBC, such a mutation in $N$. gonorrhoeae would be predicted to increase the frequency at which pilin recombinants are formed. Towards this end, we cloned the recD gene from strain MS11, determined its nucleotide sequence, and showed that the gene could complement a defined E. coli recD mutant. In addition, inactivation of the gene in MS11 increased the frequency at which non-parental pilin phenotypes were spawned. Complementation of the mutant with an intact $r e c D$ gene copy restored the frequency of pilin phenotypic variation to essentially wild-type levels. Several control experiments showed that the increased frequency of pilin variation in the gonococcal recD mutant was not due to either the decreased growth rate of piliated recD mutants or the decreased frequency of DNA transformation which was also associated with the inactivated $\mathrm{recD}$ allele.

Analysis of the gonococcal $\operatorname{rec} D$ gene revealed both similarities to homologous genes from other bacterial species and a novel feature that may have important implications with regard to the function of the putative RecBCD holoenzyme of $N$. gonorrhoeae. Several regions of amino acid identity were shared between the gonococcal RecD homologue and the RecD polypeptides of E. coli, M. tuberculosis and H. influenzae, including a conserved 'P-loop' motif (Fig. 2). The 'P-loop' motif is defined as a series of glycine residues followed by a conserved lysine and either serine or threonine (reviewed by Saraste $e t$ al., 1990). The gonococcal 'P-loop', and that of other RecD polypeptides, consisted of the amino acid residues GGPGTGKT (Fig. 2). The three-dimensional structure of the glycine-rich region is predicted to form a loop which interacts with a phosphate group of the nucleotide ATP or GTP. The conservation of the 'Ploop' in the gonococcal $\mathrm{RecD}$ polypeptide is consistent with the previous finding that the RecD protein of E. coli binds ATP (Julin \& Lehman, 1987). In contrast to $E$. coli, H. influenzae and M. tuberculosis, the gonococcal $r e c D$ gene was not linked to either the recB or recC genes. In $E$. coli, the $r e c D$ gene is directly downstream of the $\operatorname{rec} B$ gene and the genes may be expressed as part of an operon (Amundsen et al., 1986; Finch et al., 1986b). The lack of genetic linkage of the $r e c D$ and the $r e c B$ and $r e c C$ genes in the gonococcus may significantly affect their coordinate expression. Moreover, the small intergenic region between the gene encoding a putative $A B C$ transporter and the downstream recD gene in MS11 suggests that expression of $r e c D$ may be linked to the expression of the putative $\mathrm{ABC}$ transporter gene. In general, $A B C$ transporters are expressed in response to environmental conditions such as the presence of a specific substrate (reviewed by Higgins, 1992). As a result, it seems reasonable to speculate that under certain physiological conditions, the gonococcus may exist as a $\mathrm{RecD}^{-}$phenocopy, similar in phenotype to a recD mutant. Thus the enhanced frequency of pilin phenotypic variation observed in this study, following inactivation of the recD gene, may occur in vivo under certain physiological conditions in which the expression of $r e c D$ is not strictly coordinated with that of $\operatorname{rec} B$ or $r e c C$. Such a strategy could represent yet another means used by the gonococcus to alter its genetic composition.

The gonococcal recD gene restored Exo $\mathrm{V}$ activity to an E. coli recD mutant; however, the activity was not 
restored to the levels observed in the parental $\mathrm{rec}^{+}$strain. Several possibilities could account for this observation, including inefficient expression of the gonococcal recD gene in $E$. coli. Although the gene was introduced into $E$. coli on a multi-copy plasmid there are no experimental data regarding the relative expression of the gonococcal recD gene in E. coli compared to expression in $N$. gonorrboeae. In addition, the association of the gonococcal RecD subunit with the heterologous RecB and RecC subunits of $E$. coli may be inefficient or result in an enzyme with decreased enzymic activity.

Surprisingly, the frequency of DNA transformation in the MS11 recD mutant was approximately threefold lower compared to both the wild-type MS11 strain and the recD merodiploid, in contrast to the apparent increase in the frequency of intrachromosomal recombination at pilE associated with this mutation. Although the decrease was not quite statistically significant, the results were consistent upon repeated experiments. Several possible explanations could account for these disparate $\operatorname{rec} D$ mutant phenotypes. One possibility is that the pathway used for transformation-mediated recombination is not identical to that used for intrachromosomal recombination. We recently showed that during DNA transformation of competent gonococci, donor DNA is converted, at least partially, to a singlestranded form (Chaussee \& Hill, 1998). It is conceivable then that only single-stranded donor DNA is transported to the cytoplasm of competent gonococci, which would make it unlikely that the putative RecBCD pathway of recombination would be involved in recombination since the holoenzyme acts primarily on double-stranded DNA substrates. However, this rationale does not explain the decrease in the frequency of transformationmediated recombination associated with an inactivated recD allele. One possible explanation is that there is a compensatory enhancement of ATP-independent nuclease activity in an Exo V mutant $\left(\operatorname{RecD}^{-}\right)$, similar to that observed in an E. coli recD mutant (Table 3). The nuclease activity in an $E$. coli recD mutant is dependent on RecBC and involves the recJ and xon $A$ genes which both encode single-stranded nucleases (Rinken et al., 1992). Thus the decreased frequency of DNA transformation in a recD mutant of gonococci may be due to enhanced degradation of single-stranded transforming DNA and an associated decrease in the formation of recombinants. Alternatively, if transforming DNA is predominantly double-stranded following transport to the cytoplasm, the helicase activity of RecBC may create single-stranded DNA which would then be susceptible to RecJ or other single-stranded exonucleases which may have increased activity in an Exo $\mathrm{V}$ mutant, also resulting in a decrease in the frequency of DNA transformation.

In this study, differences in colony morphology were used to estimate the frequency of pilin variation among isogenic strains of MS11. As additional evidence that the variations in colony morphology correlated with changes at the pilE locus, the nucleotide sequences of the pilE genes from a total of 20 colonies which exhibited a non-parental pilin phenotype were determined. In each case, a non-parental pilin polypeptide was encoded at pilE. Although the majority of changes in colony morphology scored in this study were among piliated colonies, non-piliated variants were also scored as presenting a non-parental pilin phenotype. Since phase variation of pilin expression can result from both antigenic variation related recombination and unrelated events [including pilC phase variation and deletion of the pilE gene (Meyer et al., 1984; reviewed by Swanson \& Koomey, 1989)], the frequency of pilin phenotype variation reported here is not necessarily specific to antigenic variation. However, no difference was detected in the frequency of colony opacity phase variation among the isogenic strains, which suggests that phase variation, in general, is not affected by inactivation of the $\operatorname{recD}$ gene (S. A. Hill, unpublished results).

The increased frequency at which colonies with nonparental pilin colony morphology were spawned in $r e c D$ mutants of MS11 could be either directly or indirectly associated with the $r e c D$ mutation, since essentially nothing is known about the various pathways of homologous recombination that may exist in gonococci, the manner in which these hypothetical pathways interact, or the potential role of Chi. Genes encoding polypeptides with similarity to both the RecB and RecC polypeptides of $E$. coli are present in the genome database of N. gonorrboeae FA1090 (Roe et al., 1998). Thus while the presence of the gonococcal RecBCD holoenzyme has not been experimentally established, the phenotype of the MS11 recD mutant suggests that the RecBCD holoenzyme is functional in N. gonorrhoeae. Nonetheless, we can only speculate on the molecular mechanism that may be responsible for the increase in pilin variation in $r e c D$ mutants. Clearly, the generation of additional defined gonococcal rec mutants, in conjunction with in vivo physical analysis of recombination intermediates, is needed to define the molecular events involved in pilin antigenic variation.

\section{ACKNOWLEDGEMENTS}

We thank Thomas Meyer for providing the $\operatorname{com} A:$ : cat allele; Frank Stahl for providing phage and E. coli strains; Chris Grant, Steve Porcella and Jos van Putten for critical review of the manuscript; and Gary Hettrick and Bob Evans for help in making the figures. Oligonucleotides were designed based on sequence data provided by the Gonococcal Genome Sequencing Project and B. A. Roe, S. P. Lin, L. Song, X. Yuan and D. W. Dyer; supported by USPHS/NIH grant number AI38399.

\section{REFERENCES}

Amundsen, S. K., Taylor, A. F., Chaudhury, A. M. \& Smith, G. R. (1986). recD: the gene for an essential third subunit of exonuclease V. Proc Natl Acad Sci USA 83, 5558-5562.

Appleyard, R. K. (1954). Segregation of new lysogenic types during growth of a doubly lysogenic strain derived from Escherichia coli K12. Genetics 39, 440-452. 
Biswas, G. D., Lacks, S. A. \& Sparling, P. F. (1989). Transformation-deficient mutants of piliated Neisseria gonorrhoeae. J Bacteriol 171, 657-664.

Brcic-Kostic, K., Salaj-Smic, E., Marsic, E., Kajic, S., Stojilkovic, I. \& Trgovcevic, Z. (1991). Interaction of RecBCD enzyme with DNA damaged by gamma radiation. Mol Gen Genet 228, 136-142.

Chaussee, M. S. \& Hill, S. A. (1998). Formation of single-stranded DNA during DNA transformation of Neisseria gonorrhoeae. J Bacteriol 180, 5117-5122.

Clark, A. J. (1973). Recombination-deficient mutants of E. coli and other bacteria. Annu Rev Genet 7, 67-86.

Cole, S. T., Brosch, R., Parkhill, J. \& 39 other authors (1998). Deciphering the biology of Mycobacterium tuberculosis from the complete genome sequence. Nature 393, 537-544.

Dixon, D. A. \& Kowalczykowski, S. C. (1993). The recombination hotspot, $\mathrm{Chi}$, is a regulatory sequence that acts by attenuating the nuclease activity of the Escherichia coli recBCD enzyme. Cell 73, 87-96.

Facius, D. \& Meyer, T. F. (1993). A novel determinant (comA) essential for natural transformation competence in Neisseria gonorrhoeae and the effect of a comA defect on pilin variation. Mol Microbiol 10, 699-712.

Finch, P. W., Storey, A., Brown, K., Hickson, I. D. \& Emmerson, P. T. (1986a). Complete nucleotide sequence of recD, the structural gene for the alpha subunit of exonuclease $\mathrm{V}$ of Escherichia coli. Nucleic Acids Res 14, 8583-8594.

Finch, P. W., Wilson, R. E., Brown, K., Hickson, I. D. \& Emmerson, P. T. (1986b). Complete nucleotide sequence of the Escherichia coli recC gene and of the thyA-recC intergenic region. Nucleic Acids Res 14, 4437-4451.

Fleischmann, R. D., Adams, M. D., White, 0. \& 37 other authors (1995). Whole-genome random sequencing and assembly of Haemophilus influenzae Rd. Science 269, 496-512.

Gibbs, C. P., Reimann, B.-Y., Schulz, E., Kaufmann, A., Haas, R. \& Meyer, T. F. (1989). Reassortment of pilin genes in Neisseria gonorrhoeae occurs by two distinct mechanisms. Nature 338, $651-652$

Haas, R. \& Meyer, T. F. (1986). The repertoire of silent pilus genes in Neisseria gonorrhoeae: evidence for gene conversion. Cell 44, 107-115.

Higgins, C. F. (1992). ABC transporters: from microorganisms to man. Annu Rev Cell Biol 8, 67-113.

Hill, S. A. (1996). Limited variation and maintenance of tight genetic linkage characterize heteroallelic pilE recombination following DNA transformation of Neisseria gonorrboeae. Mol Microbiol 20, 507-518.

Hill, S. A., Morrison, S. G. \& Swanson, J. (1990). The role of direct oligonucleotide repeats in gonococcal pilin gene variation. $\mathrm{Mol}$ Microbiol 4, 1341-1352.

Hill, S. A., Stahl, M. M. \& Stahl, F. W. (1997). Single-strand DNA intermediates in phage $\lambda$ 's Red recombination pathway. Proc Natl Acad Sci USA 94, 2951-2956.

Julin, D. A. \& Lehman, E. R. (1987). Photoaffinity labeling of the recBCD enzyme of Escherichia coli with 8-azidoadenosine 5'triphosphate. J Biol Chem 262, 9044-9051.

Kellogg, D. S., Peacock, W. L., Deacon, W. E., Brown, L. \& Pirkle, C. I. (1963). Neisseria gonorrboeae. I. Virulence genetically linked to colonial variation. J Bacteriol 85, 1274-1279.

Koomey, J. M. \& Falkow, S. (1987). Cloning of the recA gene of Neisseria gonorrboeae and construction of gonococcal recA mutants. J Bacteriol 169, 790-795.
Koomey, M., Gotschlich, E. C., Robbins, K., Bergstrom, S. \& Swanson, J. (1987). Effects of recA mutations on pilus antigenic variation and phase transitions in Neisseria gonorrboeae. Genetics 117, 391-398.

Kowalczykowski, S. C., Dixon, D. A., Eggleston, A. K., Lauder, S. D. \& Rehrauer, W. M. (1994). Biochemistry of homologous recombination in Escherichia coli. Microbiol Rev 58, 401-465.

Kuzminov, A., Schabtach, E. \& Stahl, F. W. (1994). Chi sites in combination with RecA protein increase the survival of linear DNA in Escherichia coli by inactivating exoV activity of RecBCD nuclease. EMBO J 13, 2764-2776.

Lovett, S. T., Luisi-DeLuca, C. \& Kolodner, R. D. (1988). The genetic dependence of recombination in recD mutants of Escherichia coli. Genetics 120, 37-45.

McKittrick, N. H. \& Smith, G. R. (1989). Activation of Chi recombinational hotspots by RecBCD-like enzymes from enteric bacteria. J Mol Biol 210, 484-495.

Meyer, T. F., Billyard, E., Haas, R., Storzbach, S. \& So, M. (1984). Pilus genes of Neisseria gonorrhoeae: chromosomal organization and DNA sequence. Proc Natl Acad Sci USA 81, 6110-6114.

Miesel, L. \& Roth, J. R. (1994). Salmonella recD mutations increase recombination in a short sequence transduction assay. $J$ Bacteriol 176, 4092-4103.

Mulligan, M. E., Hawley, D. K., Entriken, R. \& McClure, W. R. (1984). Escherichia coli promoter sequences predict in vitro RNA polymerase selectivity. Nucleic Acids Res 12, 789-800.

Myers, R. S. \& Stahl, F. W. (1994). Chi and the RecBCD enzyme of Escherichia coli. Annu Rev Genet 28, 49-70.

Myers, R. S., Kuzminov, A. \& Stahl, F. W. (1995a). The recombination hot-spot chi activates RecBCD recombination by converting Escherichia coli to a recD mutant phenocopy. Proc Natl Acad Sci USA 92, 6244-6248.

Myers, R. S., Stahl, M. M. \& Stahl, F. W. (1995b). Chi recombination activity in phage lambda decays as a function of genetic distance. Genetics 141, 805-812.

Perry, A. C., Nicolson, I. J. \& Saunders, J. R. (1987). Structural analysis of the pilE region of Neisseria gonorrhoeae. Gene 60 , 85-92.

Rinken, R., Thoms, B. \& Wackernagel, W. (1992). Evidence that recBC-dependent degradation of duplex DNA in Escherichia col recD mutants involves DNA unwinding. $J$ Bacteriol 174, 54245429.

Roe, B. A., Lin, S. P., Song, L., Yuan, X., Clifton, S. \& Dyer, D. W. (1998). Gonococcal genome sequencing project. Web site URL: http://www.genome.ou.edu/gono.html

Russell, C. B., Thaler, D. S. \& Dahlquist, F. W. (1989). Chromosomal transformation of Escherichia coli recD strains with linearized plasmids. J Bacteriol 171, 2609-2613.

Sambrook, J., Fritsch, E. F. \& Maniatis, T. (1989). Molecular Cloning: a Laboratory Manual, 2nd edn. Cold Spring Harbor, NY: Cold Spring Harbor Laboratory.

Sandler, S. J. (1996). Overlapping functions of recF and priA in cell viability and UV-inducible SOS expression are distinguished by dnaC809 in Escherichia coli K-12. Mol Microbiol 19, 871-880.

Saraste, M., Sibbald, P. R. \& Wittinghofer, A. (1990). The P-loop - a common motif in ATP- and GTP-binding proteins. Trends Biochem Sci 15, 430-434.

Sargentini, J. J. \& Smith, K. C. (1986). Characterization and quantification of DNA strand breaks requiring recA-dependent repair in X-irradiated Escherichia coli. Radiat Res 105, 180-186. 
Seifert, H. S. (1996). Questions about gonococcal phase- and antigenic variation. Mol Microbiol 21, 433-440.

Seifert, H. S., Ajioka, R. S., Marchal, C., Sparling, P. F. \& So, M. (1988). DNA transformation leads to pilin antigenic variation in Neisseria gonorrhoeae. Nature 24, 392-395.

Smith, J. M., Dowson, C. G. \& Spratt, B. G. (1991). Localized sex in bacteria. Nature 349, 29-31.

Sparling, P. F. (1966). Genetic transformation of Neisseria gonorrhoeae to streptomycin resistance. J Bacteriol 92, 1364-1371.

Swanson, J. (1973). Studies on gonococcus infection. IV. Pili: their role in attachment of gonococci to tissue culture cells. J Exp Med 137, 571-589.

Swanson, J. (1982). Colony opacity and protein II compositions of gonococci. Infect Immun 37, 359-368.

Swanson, J. \& Koomey, J. M. (1989). Mechanism for variation of pili and outer membrane protein II in Neisseria gonorrhoeae. In Mobile DNA. Edited by D. E. Berg \& M. M. Howe. Washington, DC: American Society for Microbiology.

Swanson, J., Kraus, S. J. \& Gotschlich, E. C. (1971). Studies on gonococcus infection. I. Pili and zones of adhesion: their relation to gonococcal growth patterns. J Exp Med 134, 886-906.
Swanson, J., Bergstrom, S., Robbins, K., Barrera, O., Corwin, D. \& Koomey, J. M. (1986). Gene conversion involving the pilin structural gene correlates with pilus + in equilibrium with piluschanges in Neisseria gonorrhoeae. Cell 47, 267--276.

Swanson, J., Robbins, K., Barrera, O., Corwin, D., Boslego, J., Ciak, J., Blake, M. \& Koomey, J. M. (1987). Gonococcal pilin variants in experimental gonorrhea. $J$ Exp Med 165, 1344-1357.

Swanson, J., Morrison, S., Barrera, O. \& Hill, S. (1990). Piliation changes in transformation-defective gonococci. J Exp Med 171, 2131-2139.

Swanson, J., Belland, R. J. \& Hill, S. A. (1992). Neisserial surface variation: how and why? Curr Opin Genet Dev 2, 805-811.

Thaler, D. S., Sampson, E., Siddiqi, I., Rosenberg, S. M., Thomason, L. C., Stahl, F. W. \& Stahl, M. M. (1989). Recombination of bacteriophage lambda in recD mutants of Escherichia coli. Genome 31, 53-67.

Zhang, Q. Y., DeRyckere, D., Lauer, P. \& Koomey, M. (1992). Gene conversion in Neisseria gonorrboeae : evidence for its role in pilus antigenic variation. Proc Natl Acad Sci USA 89, 5366-5370.

Received 14 September 1998; accepted 3 November 1998. 